\title{
Synthesis of Novel $\mathrm{H}_{8}$-Binaphthol-based Chiral Receptors and Their Applications in Enantioselective Recognition of 1,2-Amino alcohols and Chirality Conversion of L-Amino acids to D-Amino acids
}

\author{
Hyein Jung, Raju Nandhakumar, Hoe-Jin Yoon, Sang-gi Lee, and Kwan Mook Kim* \\ Department of Chemistry and Nano Science (BK21), Ewha Womans University, Seoul 120-750, Korea \\ *E-mail:kkmook@ewha.ac.kr(KMK);sanggi@ewha.ac.kr(SGL) \\ Received February 8, 2010, Accepted March 10, 2010
}

\begin{abstract}
Novel $\mathrm{H}_{8}$-binaphthol-based chiral receptors appended with an uryl moiety (2a) and a guanidinium moiety (2b) have been designed and synthesized for the enantioselective recognition of 1,2-amino alcohols via reversible imine formation. The selectivities $\left(K_{R} / K_{S}=9.8 \sim 19.4\right)$ of $\mathbf{2 b}$ in imine formation with 1,2-amino alcohols are higher than those of $2 \mathbf{a}\left(K_{R} / K_{S}=1.8 \sim 4.5\right)$. Similar efficiency trend have been observed in the conversion of L-amino acids to D-amino acids, i.e., the efficiency of the receptor $\mathbf{2} \mathbf{b}$ (D/L ratio: $4.3 \sim 10.1$ ) is superior to $2 \mathbf{a}$ (D/L ratio: $4.0 \sim 8.7$ ).
\end{abstract}

Key Words: Octahydrobinaphthol, Chirality conversion, Amino acid, Amino alcohol, Enantioselective recognition

\section{Introduction}

Enantiomerically pure amino acids and amino alcohols are extremely useful starting materials or intermediates for the synthesis of a variety of biologically active chiral molecules. ${ }^{1}$ They also serve as building blocks for ligand design in the development of chiral catalysts. ${ }^{2}$ Over the years, different kinds of receptors for amines, ${ }^{3}$ amino alcohols ${ }^{4}$ and amino acids ${ }^{5}$ have been developed to discriminate the enantiomeric pairs or to enrich one enantiomer from racemic mixtures. ${ }^{6}$ In most of these studies, molecular recognition is based on non-covalent interactions such as hydrogen bonding, metal coordination, and hydrophobic interactions. In contrast, reversible covalent bond, more specifically imine formation has been rarely explored for the recognition studies. When compared to non-covalent interactions, imine bonds ${ }^{7}$ are slower to form but have the advantage of being much stronger and structurally well-defined, which are the desirable feature for developing stereoselective receptors. We recently developed a new type of binaphthol-based chiral receptors $\mathbf{1} \mathbf{a}, \mathbf{b}^{8}$ which dramatically increase the rate and equilibrium constants for imine formation through the internal resonance assisted hydrogen bonds (RAHB) (Figure 1a). ${ }^{9}$ The receptors 1a,b exhibited high efficiency in enantioselective recognition and resolution of 1,2-amino alcohols. These receptors are also good biomimetic chirality conversion reagents (CCRs), as they convert the L-form to D-form in amino acids ${ }^{10}$ and peptides. ${ }^{11}$ In nature, L-amino acids are racemized by pyridoxal phosphate (PLP) dependent enzymes. ${ }^{12}$ The racemization is occurred through the acidification of the $\alpha$ proton of the amino acid in the Schiff base formed between the PLP and an amino acid. ${ }^{13}$ The receptors $\mathbf{1 a}, \mathbf{b}$ have the capability to form Schiff bases like PLP. In contrast to PLP, the receptors $\mathbf{1 a}, \mathbf{b}$ deracemize the bound amino acids due to the chirality of binaphthyl moiety.

Though these receptors are effective for enantiomeric recognitions, for practical application of this system, it is still needed to improve the selectivities as well as the solubility of the receptors in organic solvents. However, replacement of the hydrogen bonding groups (uryl and guanidinium) to heterocyclic moieties capable of hydrogen bondings, such as pyrrole-, imidazole-, benzoimidazole-, and indole-carboxamides, ${ }^{14} \mathrm{did}$ not improve the efficiency in enantioselective recognition of 1,2-amino alcohols. In present work, we attempted to modify the binaphthyl chiral backbone by using the octahydro-1,1'-binaphthyl ( $\mathrm{H}_{8}$-binaphthyl) moiety. Although it can be expected that receptors $\mathbf{2} \mathbf{a}, \mathbf{b}$ would have similar working modes with $\mathbf{1 a}$, b favoring the formation of imines $\mathbf{B}$ over $\mathbf{A},{ }^{8,10}$ the $\mathrm{H}_{8}$-binaphthyl moiety ${ }^{15}$ provide additional features such as a sufficiently enlarged dihedral angle for better stereo-discrimination, favorable solubility and modified electronic properties as compared to its binaphthyl analogues (Figure 1b). Herein we report the detailed synthetic procedures of the receptors $\mathbf{2} \mathbf{a}, \mathbf{b}$ and their efficacies in enantioselective recognition towards the amino alcohols and as CCRs in the conversions of L-amino acids to D-amino acids.

\section{Results and Discussion}

Synthesis of receptors $\mathbf{2 a}$ and $\mathbf{2 b}$. The synthetic routes for the optically pure uryl-appended receptor $\mathbf{2} \mathbf{a}$ and guanidiniumappended receptor $\mathbf{2 b}$ are described in Scheme 1 and 2, respectively. The required common intermediate, mono MOM-protected carboxaldehyde 5, can be synthesized in two steps, starting from the commercially available optically pure $(S)-\mathrm{H}_{8}$-binaphthol 3. The direct ortho formylation could be accomplished according to the reported procedure, ${ }^{16}$ and thus, reaction of $\mathbf{3}$ with magnesium chloride and paraformaldehyde produced the mono aldehyde 4 in $69 \%$ yield. The selective mono protection of 4 with MOM chloride in DMF afforded the desired mono MOM protected $\mathrm{H}_{8}$-binaphthyl aldehyde 5. Addition of 3phenyluryl-benzyl bromide led to the formation of the MOM protected compound $\mathbf{6}$, which upon hydrolysis under acidic 
<smiles>[R]NC([X])Nc1cccc(COc2ccc3ccccc3c2-c2c(O)c(C=O)cc3ccccc23)c1</smiles>

1 1a, 2a: $X=O, R=P h$

1b, $2 \mathrm{~b}: \mathrm{X}=\mathrm{NH}_{2}{ }^{+} \mathrm{Cl}^{-}, \mathrm{R}=\mathrm{H}$

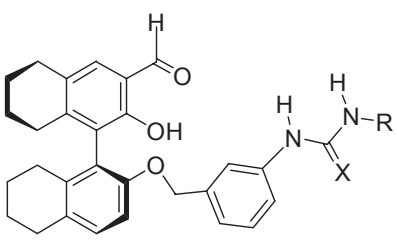

2

b)

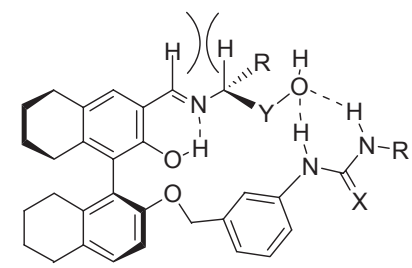

A

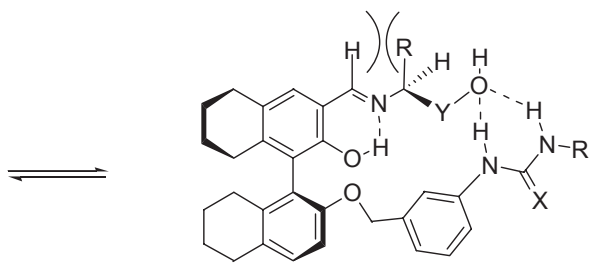

$\mathrm{Y}=\mathrm{CH}_{2}, \mathrm{CO}$

Figure 1. a) The structures of chiral receptors $\mathbf{1}$ and $\mathbf{2}$ and $\mathrm{b})$ imines of $\mathbf{2}$ formed with amino alcohols $\left(\mathrm{Y}=\mathrm{CH}_{2}\right)$ and amino acids $(\mathrm{Y}=\mathrm{CO})$.

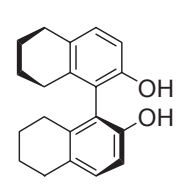

3

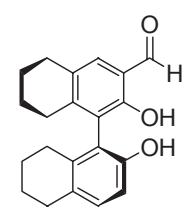

4
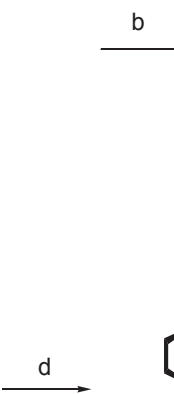

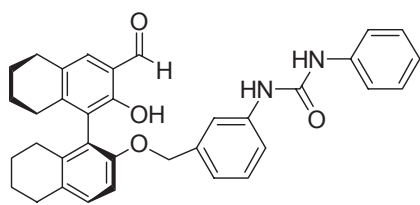

Scheme 1. Reagents and conditions: (a) $\mathrm{MgCl}_{2}$, triethylamine, paraformaldehyde, THF, $12 \mathrm{~h}$, reflux, $69 \%$; (b) $\mathrm{MOMCl}, \mathrm{NaH}, \mathrm{DMF},-50{ }^{\circ} \mathrm{C}$, $3 \mathrm{~h}, 79 \%$; (c) 3-phenyluryl-benzyl bromide, DMF, NaH, 5 h, rt, 67\%; (d) $1 \mathrm{M} \mathrm{HCl}, \mathrm{EtOH}, 60{ }^{\circ} \mathrm{C}, 3$ h, $90 \%$.

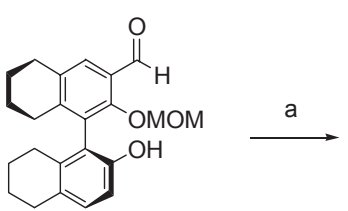

5

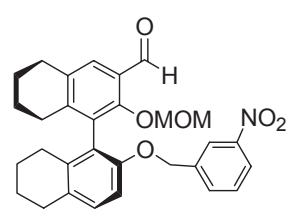

7

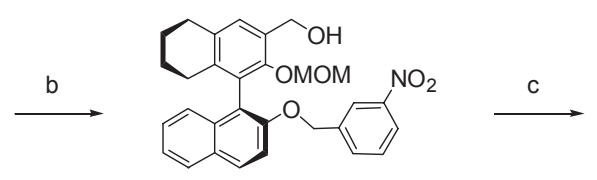

8

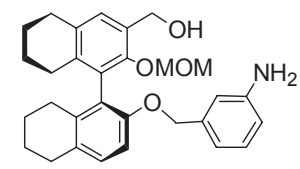

9

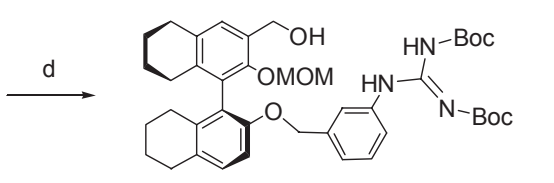

10
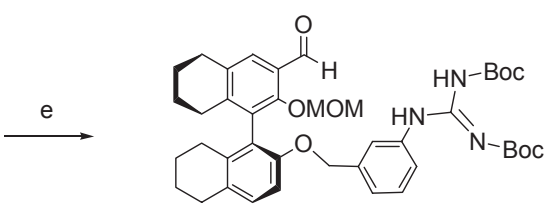

11

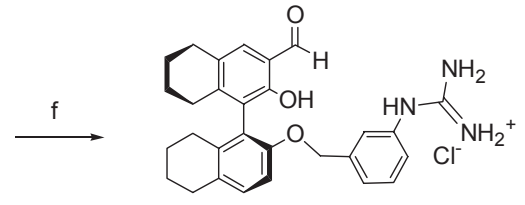

2b

Scheme 2. Reagents and conditions: (a) 3-nitrobenzylbromide, NaH, DMF, rt, 4h, 90\%; (b) $\mathrm{NaBH}_{4}, \mathrm{MeOH}, 4 \mathrm{~h}, \mathrm{rt}, 95 \%$; (c) Fe, $\mathrm{NH} 4 \mathrm{Cl}, \mathrm{EtOH}$, Dioxane, $\mathrm{H}_{2} \mathrm{O}, 80^{\circ} \mathrm{C}, 24 \mathrm{~h}, 95 \%$; (d) 1,3-bis(BOC)-2-methyl-2-thiopseudourea, TEA, $\mathrm{HgCl}_{2}$, DMF, rt, 24 h, $92 \%$; (e) PCC, methylenechloride, $5 \mathrm{~h}, \mathrm{rt}, 80 \%$; (f) $0.1 \mathrm{M} \mathrm{HCl}$, THF, reflux, $6 \mathrm{~h}, 65 \%$. 
(d)
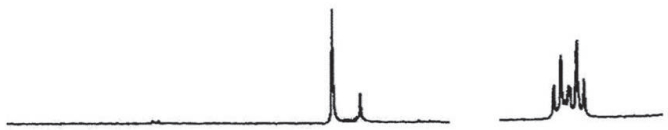

(c)
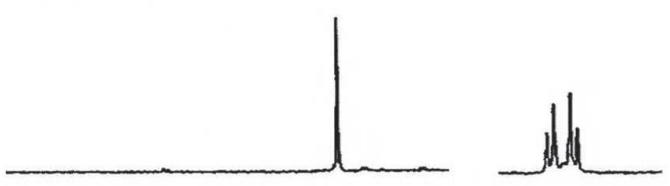

(b)
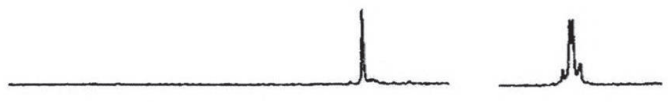

(a)
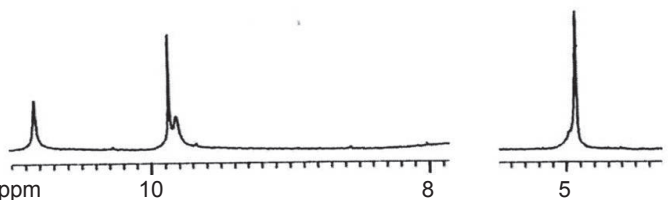

Figure 2. Partial ${ }^{1} \mathrm{H}$ NMR spectra in $\mathrm{CDCl}_{3}$ of (a) $\mathbf{2 b}$, (b) $\mathbf{2 b}$-S-ap, (c) $\mathbf{2 b}$-R-ap and(d) mixture of $\mathbf{2 b}$-S-ap and $\mathbf{2 b}$-R-ap formed by the addition of 2 equiv of racemic ap to $\mathbf{2} \mathbf{b}$.

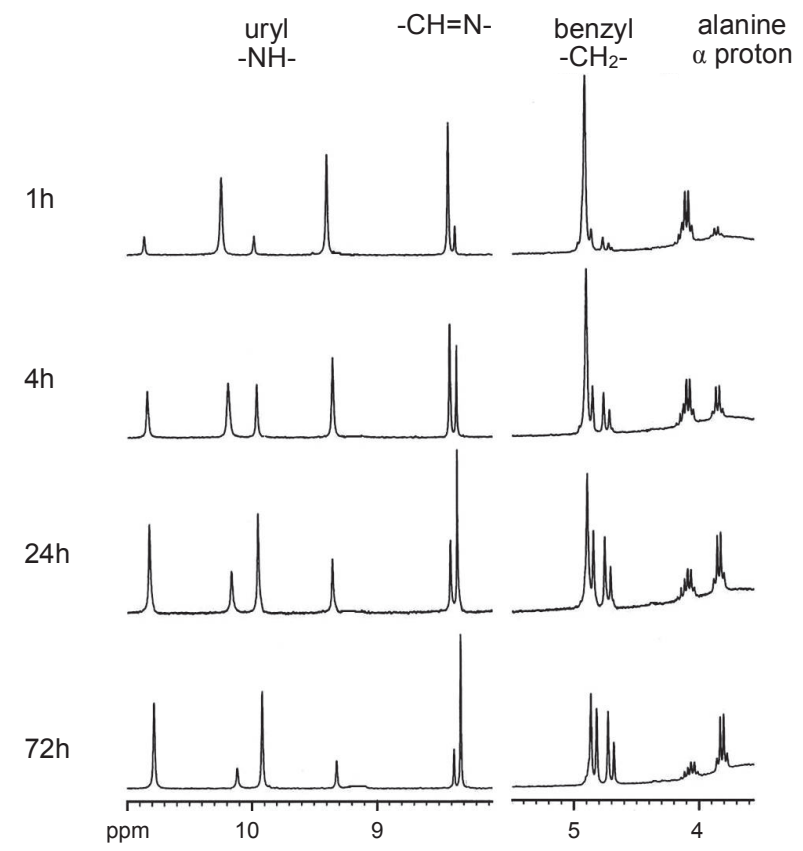

Figure 3. Time-dependent ${ }^{1} \mathrm{H}$ NMR of 2a-L-Alanine in DMSO- $d_{6}$ in the presence of 4 equiv $\mathrm{Et}_{3} \mathrm{~N}$.

condition gave the optically pure $\mathbf{2 a}$.

For the synthesis of guanidinium-appended receptor $\mathbf{2} \mathbf{b}$, the mono MOM protected $\mathrm{H}_{8}$-binaphthyl aldehyde $\mathbf{5}$ was reacted with 3-nitrobenzyl bromide to afford 7 (Scheme 2). Subsequent reductions of the aldehyde and nitro groups with sodium borohydride and iron, respectively, afforded the MOM protected alcohol 9. Coupling of amine group of 9 with 1,3-bis(BOC)-2methyl-2-thiopseudourea provided the di-BOC protected guanidine $\mathbf{1 0}$ in high yield (92\%). Oxidation of benzyl alcohol 10
Table 1. The stereoselectivities $\left(K_{R} / K s\right)$ for the imine formation of receptors $\mathbf{2 a}$ and $\mathbf{2 b}$ in $\mathrm{CDCl}_{3}$ determined by ${ }^{1} \mathrm{H}$ NMR analysis

\begin{tabular}{ccc}
\hline \multirow{2}{*}{ Amino alcohol } & \multicolumn{2}{c}{ Selectivity $\left(K_{R} / K s\right)$} \\
\cline { 2 - 3 } & $\mathbf{2 a}(\mathbf{1 a})^{a}$ & $\mathbf{2 b}(\mathbf{1 b})^{a}$ \\
\hline 2-amino-1-propanol & $3.8(3.7)$ & $16.4(11)$ \\
2-amino-1-butanol & $4.5(3.1)$ & $13.2(15)$ \\
Phenylalaninol & $3.7(3.7)$ & $9.8(8.3)$ \\
Valinol & 3.1 & $19.4(12)$ \\
Leucinol & 1.8 & $14.4(7.4)$ \\
\hline
\end{tabular}

${ }^{a}$ Data from reference $8 b$.

with pyridinium chlorochromate (PCC), followed by hydrolytic deprotection of the Boc group under acidic conditions provided the optically pure guanidnium based receptor $\mathbf{2 b}$. The structures of the receptors $\mathbf{2} \mathbf{a}$ and $\mathbf{2} \mathbf{b}$ were clearly confirmed by ${ }^{1} \mathrm{H} \mathrm{NMR}$, ${ }^{13} \mathrm{C}$ NMR and HRMS analyses. It is also notable that they are freely soluble in various organic solvents including DMSO, $\mathrm{CHCl}_{3}$ and benzene.

Enantioselective recognition of 1,2-amino alcohols with the receptors $2 \mathbf{a}$ and $\mathbf{2 b}$. Figure $2 \mathrm{a}$ shows partial ${ }^{1} \mathrm{H}$ NMR spectra of $\mathbf{2} \mathbf{b}$ in $\mathrm{CDCl}_{3}$, where the aldehyde signal appears at $9.90 \mathrm{ppm}$, -OH signal at $9.85 \mathrm{ppm}$, and benzylic $-\mathrm{CH}_{2}$ signal at $4.95 \mathrm{ppm}$. Addition of an equivalent of $(S)$-2-aminopropanol ( $(S)$-ap) resulted in complete and rapid decrease of the intensity of aldehyde signal with concomitant increase of the signal at $8.55 \mathrm{ppm}$, which corresponds to the imine $\mathrm{C}-\mathrm{H}$ proton of $\mathbf{2 b}$-S-ap (Figure $2 \mathrm{~b})$. On the other hand, addition of an equivalent of $(R)$-ap to $\mathbf{2 b}$ showed complete formation of imine $\mathbf{2} \mathbf{b}$ - R-ap with its $\mathrm{C}-\mathrm{H}$ proton signal appearing at $8.65 \mathrm{ppm}$ (Figure 2c). It has been also found that, aside from the imine $\mathrm{C}-\mathrm{H}$ signals, the diastereotopic benzylic $\mathrm{CH}_{2}$ signals are also useful for distinguishing $\mathbf{2 b}$-S-ap and $\mathbf{2} \mathbf{b}-\mathrm{R}$-ap. The benzylic signal of $\mathbf{2} \mathbf{b}-\mathrm{R}-\mathrm{ap}$ exhibits higher coupling constant for doublet of doublet than that of the $\mathbf{2 b - S - a p , ~ w h i c h ~ r e f l e c t s ~ t h e ~ m o r e ~ r i g i d ~ t h r e e - d i m e n - ~}$ sional structure of $\mathbf{2 b}-\mathrm{R}$-ap. Figure $2 \mathrm{~d}$ shows the ${ }^{1} \mathrm{H}$ NMR spectrum for a mixture of $\mathbf{2} \mathbf{b}$-S-ap and $\mathbf{2} \mathbf{b}$-R-ap formed by the addition of 2 equiv of racemic ap to $\mathbf{2} \mathbf{b}$. The ratio of $\mathbf{2} \mathbf{b}-\mathrm{R}$-ap and $\mathbf{2 b}-\mathrm{S}$-ap can be measured from the integration of imine $\mathrm{C}-\mathrm{H}$ and benzylic hydrogen signals. The observed 4.05:1 ratio of the two peaks indicated that the imine formation constant for 2b-R-ap $\left(K_{R}\right)$ is larger than $\mathbf{2 b}$-S-ap $\left(K_{S}\right)$ by a factor of about $4.05^{2}=16.4 .^{17}$ Even if $\mathbf{2 b}-\mathrm{S}$-ap is first formed by the addition of 1 equiv of $(S)-a p$, the above equilibrium ratio is obtained within minutes upon addition of 1 equiv $(R)$-ap.

We studied the stereoselectivities in imine formation $\left(K_{R} / K_{S}\right)$ of the two receptors $\mathbf{2} \mathbf{a}$ and $\mathbf{2 b}$ with five representative racemic 1,2-amino alcohols such as 2-amino-1-propanol, 2-amino-1butanol, 2-amino-3-phenyl-1-propanol (phenylalaninol), 2-amino-3-methyl-1-butanol (valinol), and 2-amino-4-methyl-1-pentanol (leucinol) by ${ }^{1} \mathrm{H}$ NMR analysis. The results are summarized in Table 1, in which the selectivities obtained with binaphthol-based receptors $\mathbf{1} \mathbf{a}, \mathbf{b}$ were also included for comparison. ${ }^{8 \mathrm{~b}}$ As shown in Table 1 , the pronounce positive effects of $\mathrm{H}_{8}$-binaphthol have been observed, in both the uryl based $\mathbf{2 a}$ and the guanidinium-based receptor $\mathbf{2 b}$, which exhibited 
Table 2. The conversion efficiency of the receptors $\mathbf{2 a} \mathbf{a}, \mathbf{b}$ for amino acids determined by ${ }^{1} \mathrm{H}$ NMR anaylsis

\begin{tabular}{ccc}
\hline \multirow{2}{*}{ Amino acid } & \multicolumn{2}{c}{$\mathrm{D} / \mathrm{L}$ ratio } \\
\cline { 2 - 3 } & $\mathbf{2 a}(\mathbf{1 a})^{a}$ & $\mathbf{2 b}(\mathbf{1 b})^{a}$ \\
\hline Alanine & $4.0(7)$ & $4.4(1.9)$ \\
Asparagine & $8.1(13)$ & $10.1(2.9)$ \\
Glutamine & $6.1(15)$ & $8.0(3.3)$ \\
Histidine & $8.7(14)$ & $4.3(12)$ \\
Phenylalanine & $6.5(11)$ & $4.5(2.2)$ \\
Serine & $7.9(11)$ & $5.6(2.2)$ \\
Tyrosine & $8.4(12)$ & $4.9(3.2)$ \\
\hline
\end{tabular}

${ }^{a}$ Data from reference 10c.

higher selectivities than their binaphthyl analogues 1a and $\mathbf{1 b},{ }^{8 b}$ may be due to the enlarged dihedral angle caused by the tetralin moieties. The higher selelectivities of the guadiniumbased $\mathbf{1 b}$ and $\mathbf{2 b}$ than those of the uryl-based $1 \mathbf{a}$ and $\mathbf{2 a}$ are due to the charge reinforced hydrogen bonds of guanidinium-based receptors. $^{18,8 \mathrm{~b}}$

Conversion of L-Amino acid to D-amino acid by using 1 and $\mathbf{2}$ as CCRs. We also studied the activities of receptors $\mathbf{2 a} \mathbf{a}, \mathbf{b}$ for the conversion of amino acids from L-form to D-form. The conversion effficiency was determined by ${ }^{1} \mathrm{H}$ NMR analysis. Figure 3 shows the time-dependent change of ${ }^{1} \mathrm{H}$ NMR spectra of the imine 2a-L-Ala formed between $\mathbf{2 a}(10 \mathrm{mM})$ and L-Ala $(10 \mathrm{mM})$ in the presence of 4 equiv triethylamine in DMSO- $d_{6}$. The mixing of the reagents and stirring for $1 \mathrm{~h}$ led to the complete imine formation. The peak at 9.33 and 10.13 ppm correspond to the two urea hydrogen signals, and the peak at 8.39 ppm is ascribed to the imine hydrogen signal of $\mathbf{2 a - L - A l a . ~ T h e ~}$ intensity of these peaks decrease as time goes, while new peaks corresponding to urea (9.92 and $10.80 \mathrm{ppm})$ and imine (8.31 $\mathrm{ppm}$ ) signals of 2a-D-Ala are growing. This clearly shows the chirality conversion of $\mathbf{2} \mathbf{a}-\mathrm{L}-\mathrm{Ala}$ to $\mathbf{2 a - D}-\mathrm{Ala}$. The apparent downfield shift of uryl NH protons of 2a-D-Ala compared to 2a-L-Ala is probably due to the stronger hydrogen bond between the uryl group of $\mathbf{2} \mathbf{a}$ and carboxylate group of $\mathrm{D}$-alanine. Besides urea and imine hydrogens, benzyl $-\mathrm{CH}_{2}$ - resonance signals at 4.90 for $\mathbf{2 a - L}-A l a$ and 4.80 ppm for 2a-D-Ala, and alanine $\boldsymbol{\alpha}$ proton signals at 4.05 for $2 \mathrm{a}-\mathrm{L}-\mathrm{Ala}$ and $3.80 \mathrm{ppm}$ for 2a-D-Ala are also helpful to determine the chirality conversion. The intensities of the resonance signals reach the equilibrium in $72 \mathrm{~h}$. The stereoselectivity defined by the ratio of (2a-D-Ala)/ (2a-L-Ala) is measured by the integration of the corresponding signals.

After confirming the feasibility of the ${ }^{1} \mathrm{H}$ NMR analysis to determine the selectivity, we further investigated the efficiency of the receptors $\mathbf{2} \mathbf{a}, \mathbf{b}$ for representative seven amino acids such as alanine, asparagine, glutamine, histidine, phenyl alanine, serine and tyrosine. As shown in Table 2, conversion efficiencies of the uryl-based $\mathrm{H}_{8}$-binaphthyl receptor $\mathbf{2 a}$ is inferior to the corresponding binaphthyl receptor $1 \mathbf{a}$. In contrast, the conversion efficiencies of guanidinium-based receptor $\mathbf{2} \mathbf{b}$ was dramatically increased compared to those of the corresponding $\mathbf{1 a}$ for most amino acids tested except for histidine. ${ }^{10 \mathrm{c}}$

\section{Conclusion}

In summary, two novel $\mathrm{H}_{8}$-binaphthol-derived uryl and guanidinium receptors $\mathbf{2} \mathbf{a}-\mathbf{b}$ have been synthesized and studied on the enantioselective imine formation of chiral 1,2-amino alcohols. Both the receptors showed higher selectivities than those of the previously reported binaphthol based receptors 1a-b. The enlarged dihedral angle between the two phenyl rings in the $\mathrm{H}_{8}$-binaphthyl group and modified electronic properties might have enhanced the enantioselectivities. Furthermore, compared to binaphthyl analogue $\mathbf{1 b}$, the guanidiniumbased $\mathrm{H}_{8}$-binaphthol receptor $\mathbf{2 b}$ exhibited much improved conversion efficiency as CCRs towards the natural amino acids in converting their L-form to D-form. The higher solubility of these receptors in various solvents such as DMSO, $\mathrm{CHCl}_{3}$ and benzene provides additional advantages in their usage as enantioselective recognition receptors.

\section{Experimental}

General. The (S)-5,5',6,6',7,7',8,8'-octahydro-1,1'-binaphthol (3) was purchased from TCI. All chemicals were used as received without further purifications. The solvents were dried prior to use. NMR spectra were recorded on a Bruker AM 250 spectrometer in $\mathrm{CDCl}_{3}$ and DMSO- $d_{6}$ solutions containing tetramethylsilane as internal standard. Chemical shifts are reported in $\delta$ unit. Melting points were measured with Electrothermal IA 9000 digital melting point apparatus and are uncorrected. HRMS spectra were obtained on FAB mode. For column chromatography, silica gel of 230 - 400 mesh was used.

(S)-2,2'-Dihydroxy-3-formyl-5,5',6,6',7,7',8,8'-octahydro1,1'-binaphthalene (4). To a solution of $(S)-5,5^{\prime}, 6,6^{\prime}, 7,7^{\prime}, 8,8^{\prime}-$ octahydro-1,1'-binaphthol 3 (12.0 g, $40.76 \mathrm{mmol})$ in anhydrous THF (300 mL), anhydrous magnesium chloride (7.76 g, 81.52 $\mathrm{mmol})$, triethylamine $(11.36 \mathrm{~mL}, 81.52 \mathrm{mmol})$ and paraformaldehyde $(4.0 \mathrm{~g})$ were successively added under nitrogen atmosphere, and the resulting mixture was refluxed for $12 \mathrm{~h}$. The reaction was quenched by addition of $3 \mathrm{M} \mathrm{HCl}$ solution until the $\mathrm{pH}$ becomes 7 . The solvent was evaporated and the residue was extracted with ethyl acetate. The combined organic layer was dried with $\mathrm{MgSO}_{4}$ and evaporated. The resulting residue was purified by silica-gel column chromatography (EtOAc: hexane $=1: 1)$ to yield the desired 4. Yield: $8.5 \mathrm{~g}(69 \%)$; $\mathrm{mp}$ $146-147{ }^{\circ} \mathrm{C} ;{ }^{1} \mathrm{HNMR}\left(\mathrm{CDCl}_{3}, 63 \mathrm{MHz}\right) \delta 10.89$ (s, $\left.1 \mathrm{H},-\mathrm{CHO}\right)$, 9.86 (s, 1H, -OH), 7.35-6.73 (s, dd, 3H), 4.37 (s, 1H, -OH), 2.82-1.66 (m, 16H); ${ }^{13} \mathrm{C}$ NMR $\left(\mathrm{CDCl}_{3}, 250 \mathrm{MHz}\right) \delta 192.3$, $165.4,157.3,155.7,148.6,137.9,136.3,132.5,128.5,123.3$, $120.3,28.7,27.9,27.2,27.0,23.9,23.5,23.0,22.9$.

(S)-2-Methoxymethoxy-2'-hydroxy-3-formyl-5,5',6,6', , $\mathbf{7}^{\prime}, \mathbf{8 , 8} \mathbf{8}^{\prime}$-octahydro-1,1'-binaphthalene (5). To a solution of $\mathbf{4}$ $(6.5 \mathrm{~g}, 21 \mathrm{mmol})$ in DMF $(75 \mathrm{~mL})$ was added $60 \% \mathrm{NaH}(0.79$ $\mathrm{g}, 20 \mathrm{mmol}$ ) at $0{ }^{\circ} \mathrm{C}$ in portion by portion, and stirred for $1 \mathrm{~h}$ at room temperature. After addition of chloromethyl methyl ether $(2.36 \mathrm{~g}, 31 \mathrm{mmol})$ at $0{ }^{\circ} \mathrm{C}$, the reaction mixture was stirred for $3 \mathrm{~h}$ at room temperature. The reaction mixtrure was extracted with EtOAc/water. The organic layer was dried with $\mathrm{MgSO}_{4}$, and evaporated. Recrystallization of the residue with EtOAc and hexane yielded the product 5. Yield: $6.0 \mathrm{~g}(79 \%)$; mp 139 - 
$140{ }^{\circ} \mathrm{C} ;{ }^{1} \mathrm{H} \mathrm{NMR}\left(\mathrm{CDCl}_{3}, 250 \mathrm{MHz}\right) \delta 10.26(\mathrm{~s}, 1 \mathrm{H},-\mathrm{CHO})$, 7.66-6.76 (s, dd, 3H), 4.81-4.69 (dd, $\left.2 \mathrm{H},-\mathrm{OCH}_{2}\right), 4.54$ (s, 1H, -OH), 3.13 (s, 3H, $\left.-\mathrm{OCH}_{3}\right), 2.86-1.65(\mathrm{~m}, 16 \mathrm{H}) ;{ }^{13} \mathrm{C}$ NMR $\left(\mathrm{CDCl}_{3}, 63 \mathrm{MHz}\right) \delta 190.9,156.9,155.9,150.7,148.0,146.4$, 136.1, 134.6, 130.0, 129.9, 127.3, 122.3, 100.2, 57.2, 29.5, 27.9, $27.8,27.4,27.1,23.2,23.0,22.6,22.4 ;[\alpha]_{\mathrm{D}}=-34.9(c$ 18.6, $\left.\mathrm{CHCl}_{3}\right)$.

(S)-2-Methoxymethoxy-2'-(3-phenyluryl-benzyloxy)-3-formyl-5,5',6,6',7,7',8,8'-octahydro-1,1'-binaphthalene (6). To a suspension of $\mathrm{NaH}(0.1 \mathrm{~g}, 2.45 \mathrm{mmol})$ in DMF $(5 \mathrm{~mL})$ was added the solution of 5 (1.0 g, $2.73 \mathrm{mmol})$ in DMF $(5 \mathrm{~mL})$ at $0{ }^{\circ} \mathrm{C}$ over a period of 30 minutes. After stirring for 30 minutes, 3-phenylurylbenzyl bromide ${ }^{8 \mathrm{a}}(0.58 \mathrm{~g}, 2.73 \mathrm{mmol})$ was added, and the stirring continued for an hour at room temperature. After quenching the reaction with aqueous sat. $\mathrm{NH}_{4} \mathrm{Cl}$ solution, the reaction mixture was extracted with ethyl acetate. After evaporation of solvent, the residue was purified by silica column chromatography $($ EtOAc/hexane $=1: 5)$ to afford 6. Yield: $1.01 \mathrm{~g}$ (67\%); mp $195-196{ }^{\circ} \mathrm{C} ;{ }^{1} \mathrm{H} \mathrm{NMR}\left(\mathrm{CDCl}_{3}, 250 \mathrm{MHz}\right) \delta 10.27$ (s, 1H, CHO), 7.57-6.66 (m, 12H), 4.97-4.95 (d, 2H, $\left.\mathrm{OCH}_{2}\right)$, 4.72-4.71 (dd, $\left.2 \mathrm{H}, \mathrm{OCH}_{2} \mathrm{O}\right), 2.96\left(\mathrm{~s}, 3 \mathrm{H}, \mathrm{OCH}_{3}\right), 2.81-1.59$ $(\mathrm{m}, 16 \mathrm{H}) ;{ }^{13} \mathrm{C} \mathrm{NMR}\left(\mathrm{CDCl}_{3}, 63 \mathrm{MHz}\right) \delta 189.7,162.1,155.6$, 154.7, 149.0, 139.1, 138.4, 137.5, 136.1, 135.4, 130.8, 129.9, $129.3,128.4,125.1,123.7,123.2,121.3,120.7,119.3,118.4$, $118.0,117.5,72.4,67.5,31.3,29.3,29.8,29.1,28.6,23.5,23.2$, $22.9,22.6$

(S)-2-Methoxymethoxy-2'-(3-nitrobenzy)-3-fromyl-[5,5', $\mathbf{6 , 6}, \mathbf{7}, \mathbf{7}^{\prime}, \mathbf{8 , 8}$ '-octahydro-1,1'-binaphthalene] (7). To a solution of $5(3.0 \mathrm{~g}, 8.19 \mathrm{mmol})$ in DMF $(50 \mathrm{~mL})$ was added the $60 \%$ $\mathrm{NaH}(0.33 \mathrm{~g}, 8.19 \mathrm{mmol})$ at $0{ }^{\circ} \mathrm{C}$, and the mixture was stirred for 30 minutes. After addition of the 3-nitrobenzylbromide ( $2.12 \mathrm{~g}, 8.19 \mathrm{mmol})$, the reaction mixture was stirred for $4 \mathrm{~h}$ and quenched with aqueous sat. $\mathrm{NH}_{4} \mathrm{Cl}$ solution. The mixture was extracted with with ethyl acetate, and the combined organic layers was dried with $\mathrm{MgSO}_{4}$, and evaporated. The resulting residue was purified by silica column chromatography (EtOAc/ hexane $=1: 5)$ to yield the desired 7. Yield: $4.0 \mathrm{~g}(90 \%)$; mp $110-112{ }^{\circ} \mathrm{C} ;{ }^{1} \mathrm{H} \mathrm{NMR}\left(\mathrm{CDCl}_{3}, 250 \mathrm{MHz}\right) \delta 10.29$ (s, $\left.1 \mathrm{H},-\mathrm{CHO}\right)$, 8.10-6.74 (m, 7H), 5.09 (s, 2H, $\left.-\mathrm{OCH}_{2}\right), 4.77-4.62(\mathrm{dd}, 2 \mathrm{H}$, $\left.-\mathrm{OCH}_{2} \mathrm{O}\right), 3.08\left(\mathrm{~s}, 3 \mathrm{H},-\mathrm{OCH}_{3}\right), 2.88-1.68(\mathrm{~m}, 16 \mathrm{H}) ;{ }^{13} \mathrm{C} \mathrm{NMR}$ $\left(\mathrm{CDCl}_{3}, 63 \mathrm{MHz}\right) \delta 191.8,163.4,153.3,141.8,137.3,136.7$, $133.9,132.5,131.3,129.2,129.0,128.8,128.2,127.5,126.1$, $122.4,120.8,109.3,98.5,72.5,68.2,31.5,29.6,28.7,28.1$, 27.3, 26.7, 22.8, 22.4, 21.7, 21.3.

(S)-2-Methoxymethoxy-2'-(3-nitrobenzyloxy)-3-hydroxymethyl-5,5',6,6',7,7',8,8'-octahydro-1,1'-binaphthalene] (8). To a solution of $7(4.0 \mathrm{~g}, 8.0 \mathrm{mmol})$ in methanol was added sodium borohydride $(0.36 \mathrm{~g}, 9.57 \mathrm{mmol})$, and the reaction mixture was stirred for $4 \mathrm{~h}$ at room temperature. The reaction was quenched by addition of water, and the solvent is evaporated. The product was extracted with ethyl acetate, and evaporation of ethyl acetate afforded the pure 8. Yield: $3.8 \mathrm{~g} \mathrm{(95 \% );} \mathrm{mp}$ $138-139{ }^{\circ} \mathrm{C} ;{ }^{1} \mathrm{H} \mathrm{NMR}\left(\mathrm{CDCl}_{3}, 250 \mathrm{MHz}\right) \delta 8.09-6.73(\mathrm{~m}, 7 \mathrm{H})$, 5.09 (s, 2H, $\left.-\mathrm{OCH}_{2}\right), 4.73-4.5$ (m, 2H, $\left.\mathrm{CH}_{2} \mathrm{OH}\right), 4.69-4.49$ (dd, $\left.2 \mathrm{H},-\mathrm{OCH}_{2} \mathrm{O}\right), 3.26\left(\mathrm{~s}, 3 \mathrm{H},-\mathrm{OCH}_{3}\right), 3.1(\mathrm{t}, 1 \mathrm{H},-\mathrm{OH}), 2.82-1.63$ $(\mathrm{m}, 16 \mathrm{H}) ;{ }^{13} \mathrm{C} \mathrm{NMR}\left(\mathrm{CDCl}_{3}, 63 \mathrm{MHz}\right) \delta 151.8,150.4,147.3$, 138.8, 136.3, 135.7, 132.9, 131.2, 130.7, 129.8, 129.6, 129.1, $128.3,128.0,125.1,121.4,120.2,108.4,97.9,67.5,60.5$,
$55.8,30.9,28.6,28.4,28.3,26.3,26.0,22.0,21.9,21.6,21.2$; $[\alpha]_{\mathrm{D}}=-23.3\left(c\right.$ 6.88, $\left.\mathrm{CHCl}_{3}\right)$.

(S)-2-Methoxymethoxy-2'-(3-aminobenzyloxy)-3-hydroxymethyl-5,5',6,6',7,7',8,8'-octahydro-1,1'-binaphthalene (9). To a solution of $8(4.5 \mathrm{~g}, 8.94 \mathrm{mmol})$ in a mixture of ethanol/ 1,4-dioxane/water (1:1:1) was added the iron powder (3.5 g, $62.6 \mathrm{mmol})$ and ammonium chloride $(0.86 \mathrm{~g}, 16 \mathrm{mmol})$ successively. After reflux for $24 \mathrm{~h}$, the solvent was evaporated. The residue was purified by silica gel column chromatography $($ EtOAc/hexane $=1: 5)$ to afford 9. Yield: $4.23 \mathrm{~g}(95 \%)$; mp 132 - $133{ }^{\circ} \mathrm{C} ;{ }^{1} \mathrm{H} \mathrm{NMR}\left(\mathrm{CDCl}_{3}, 250 \mathrm{MHz}\right) \delta 7.10-6.35(\mathrm{~m}, 7 \mathrm{H})$, 4.80-4.70 (m, 2H, $\left.\mathrm{CH}_{2} \mathrm{OH}\right), 4.49-4.44$ (dd, $\left.2 \mathrm{H},-\mathrm{OCH}_{2} \mathrm{O}\right), 4.92$ $\left(\mathrm{s}, 2 \mathrm{H},-\mathrm{OCH}_{2}\right), 3.28\left(\mathrm{~s}, 3 \mathrm{H},-\mathrm{OCH}_{3}\right), 2.79-1.61(\mathrm{~m}, 16 \mathrm{H}) ;{ }^{13} \mathrm{C}$ NMR $\left(\mathrm{CDCl}_{3}, 63 \mathrm{MHz}\right) \delta 163.8,163.5,153.5,151.4,138.7$, $138.5,137.0,136.9,136.6,133.6,131.6,130.9,130.1,129.9$, 129.0, 125.8, 122.9, 121.8, 120.1, 119.9, 109.6, 99.1, 98.9, 69.4, $61.5,56.8,29.7,29.5,29.4,28.1,27.3,27.2,23.1,23.0,22.9$; $[\alpha]_{\mathrm{D}}=-19.8\left(c 7.58, \mathrm{CHCl}_{3}\right)$.

(S)-2-Methoxymethoxy-3-hydroxymethyl-2'-[(3- $\left(N, N^{\prime}-\right.$ di(tert-butoxy carbonyl)-guanidino)-benzyloxy)-5,5', $\mathbf{6 , 6}, 7,7^{\prime}, 8,8^{\prime}$-octahydro-1,1'-binaphthalene (10). To a stirred solution of 9 (2.5 g, $5.31 \mathrm{mmol}$ ) and 1,3-bis-BOC-2-methyl-2thiopseudourea $(1.57 \mathrm{~g}, 5.31 \mathrm{mmol})$ in dry DMF at $0{ }^{\circ} \mathrm{C}$ under nitrogen was added triethylamine $(3.0 \mathrm{~mL}, 21.24 \mathrm{mmol})$ and $\mathrm{HgCl}_{2}$ (1.58 g, $\left.5.84 \mathrm{mmol}\right)$. The resulting suspension was stirred at $0{ }^{\circ} \mathrm{C}$ for $3 \mathrm{~h}$, and then at room temperature for overnight. The mixture was diluted with EtOAc and filtered through Celite. Evaporation of the solvent followed by silica column chromatography $($ EtOAc/hexane $=1: 3)$ gave 10. Yield: $3.5 \mathrm{~g}(92 \%)$; mp $174-175{ }^{\circ} \mathrm{C} ;{ }^{1} \mathrm{H} \mathrm{NMR}\left(\mathrm{CDCl}_{3}, 250 \mathrm{MHz}\right) \delta 11.65(\mathrm{~s}, 1 \mathrm{H}$, $\mathrm{NH}), 10.21(\mathrm{~s}, 1 \mathrm{H}, \mathrm{NH}), 7.62-6.73(\mathrm{~m}, 7 \mathrm{H}), 4.99\left(\mathrm{~s}, 2 \mathrm{H}, \mathrm{OCH}_{2}\right)$, 4.71-4.69 (m, 2H, $\left.\mathrm{CH}_{2} \mathrm{OH}\right), 4.48-4.46$ (dd, $\left.2 \mathrm{H}, \mathrm{OCH}_{2} \mathrm{O}\right), 3.25$ $\left(\mathrm{s}, 3 \mathrm{H}, \mathrm{OCH}_{3}\right), 2.79-1.62(\mathrm{~m}, 16 \mathrm{H}), 1.55-1.49(\mathrm{~m}, 18 \mathrm{H}) ;{ }^{13} \mathrm{C}$ $\mathrm{NMR}\left(\mathrm{CDCl}_{3}, 63 \mathrm{MHz}\right) \delta 163.6,155.1,153.5,152.9,151.3$, 145.2, 137.8, 136.6, 135.4, 133.7, 133.1, 130.5, 129.7, 129.1, $127.3,126.7,123.7,122.2,120.4,119.8,109.4,99.4,83.7$, $69.5,54.9,28.3,28.1,27.8,27.0,26.6,26.1,22.8,21.5,21.2$.

(S)-2-Methoxymethoxy-2'-[(3-( $N, N^{\prime}$-di(tert-butoxycarbonyl)-guanidino)-benzyl)-3-formyl-5,5',6,6',7,7',8,8'-octahydro1,1'-binaphthalene (11). To a solution of $\mathbf{1 0}$ (3.5 g, $4.89 \mathrm{mmol})$ in methylene chloride $(50 \mathrm{~mL})$ was added at room temperature the PCC (2.1 g, $9.78 \mathrm{mmol})$. After stirring for $12 \mathrm{~h}$, the mixture was passed through a short pad of celite. The filtrate was concentrated and purified by column chromatography (EtOAc/ hexane $=1: 5)$ to give 11. Yield: $2.7 \mathrm{~g}(80 \%) ; \mathrm{mp} 86-88{ }^{\circ} \mathrm{C} ;{ }^{1} \mathrm{H}$ NMR $\left(\mathrm{CDCl}_{3}, 250 \mathrm{MHz}\right) \delta 11.65(\mathrm{~s}, 1 \mathrm{H}, \mathrm{NH}), 10.36(\mathrm{~s}, 1 \mathrm{H}$, $\mathrm{CHO}), 10.24(\mathrm{~s}, 1 \mathrm{H}, \mathrm{NH}), 7.63-6.75(\mathrm{~m}, 7 \mathrm{H}), 5.00\left(\mathrm{~s}, 2 \mathrm{H}, \mathrm{OCH}_{2}\right)$, 4.78-4.61(dd, $\left.2 \mathrm{H}, \mathrm{OCH}_{2} \mathrm{O}\right), 3.09\left(\mathrm{~s}, 3 \mathrm{H}, \mathrm{OCH}_{3}\right), 2.85-1.64(\mathrm{~m}$, $16 \mathrm{H}), 1.55-1.49(\mathrm{~m}, 18 \mathrm{H}) ;{ }^{13} \mathrm{C} \mathrm{NMR}\left(\mathrm{CDCl}_{3}, 63 \mathrm{MHz}\right) \delta 189.9$, $162.5,154.3,152.5,152.2,144.3,137.2,136.0,135.8,133.1$, 133.0, 130.8, 129.1, 128.3, 126.9, 126.4, 123.6, 121.7, 120.7, $118.9,108.5,98.9,82.7,78.6,68.3,56.1,28.6,28.4,28.3,27.0$, $26.9,26.3,22.0,21.8,21.6 ;[\alpha]_{\mathrm{D}}=-13.2\left(c 18.2, \mathrm{CHCl}_{3}\right)$.

(S)-2-Hydroxy-2'-(3-phenyluryl-benzyl)-3-formyl-5,5',6,6', $7,7 ', 8,8$ '-octahydro-1, 1 '-binaphthalene (2a). The solution of 6 $(1 \mathrm{~g}, 1.829 \mathrm{mmol})$ in ethanol was treated with aqueous $\mathrm{HCl}$ $(0.48 \mathrm{~mL}, 5.49 \mathrm{mmol})$ for $3 \mathrm{~h}$ at reflux temperature. After evaporation of the solvent, the residue was purified by silica column 
chromatography $(\mathrm{EtOAc} / \mathrm{Hex}=1: 5)$ to afford the receptor $\mathbf{1}$. Yield: $0.89 \mathrm{~g}(90 \%) ; \mathrm{mp} 117-118{ }^{\circ} \mathrm{C} ;{ }^{1} \mathrm{H}$ NMR $\left(\mathrm{CDCl}_{3}, 250\right.$ $\mathrm{MHz}) \delta 10.73(\mathrm{~s}, 1 \mathrm{H}, \mathrm{CHO}), 9.69(\mathrm{~s}, 1 \mathrm{H}, \mathrm{OH}), 7.43-6.70(\mathrm{~m}$, $12 \mathrm{H}), 4.88\left(\mathrm{~s}, 2 \mathrm{H}, \mathrm{OCH}_{2}\right), 2.75-1.65(\mathrm{~m}, 16 \mathrm{H}) ;{ }^{13} \mathrm{C} \mathrm{NMR}$ $\left(\mathrm{CDCl}_{3}, 63 \mathrm{MHz}\right) \delta 196.4,156.1,153.7,153.3,147.3,138.5$, $138.2,138.1,136.8,133.2,130.4,129.7,129.4,128.9,125.6$, $123.9,123.4,121.8,120.3,119.7,118.9,118.7,110.7,70.0$, 29.3, 29.0, 28.1, 27.0, 23.0, 22.9, 22.7, 22.5; HRMS (FAB) calcd for $\mathrm{C}_{35} \mathrm{H}_{36} \mathrm{~N}_{2} \mathrm{O}_{4}$ : 548. 2675; found: 548.2669; $[\alpha]_{\mathrm{D}}=-54.8$ (c 6.02, $\mathrm{CHCl}_{3}$ ).

(S)-2-Hydroxyl-2'-(3-guanidyl-benzyloxy)-3-formyl)-5,5', $6,6^{\prime}, 7,7^{\prime}, 8,8$ '-octahydro-1, $1^{\prime}$-binaphthalene (2b). To a solution of $11(0.3 \mathrm{~g}, 0.42 \mathrm{mmol})$ in THF $(5 \mathrm{~mL})$ was added the $0.1 \mathrm{M}$ aqueous $\mathrm{HCl}(0.84 \mathrm{~mL})$ at $0{ }^{\circ} \mathrm{C}$. The temperature was slowly raised to room temperature, and then refluxed at $70^{\circ} \mathrm{C}$ for $6 \mathrm{~h}$. The solvent was evaporated and the residue was extracted with EtOAc. The combined organic layers were washed with $0.1 \mathrm{M}$ aqueous $\mathrm{HCl}$. Evaporation of the solvent yielded the pure receptor 2. Yield: $0.15 \mathrm{~g}(65 \%)$; mp $159-160{ }^{\circ} \mathrm{C} ;{ }^{1} \mathrm{H}$ NMR (CD$\left.\mathrm{Cl}_{3}, 250 \mathrm{MHz}\right) \delta 10.83(\mathrm{~s}, 1 \mathrm{H}, \mathrm{NH}), 9.90(\mathrm{~s}, 1 \mathrm{H}, \mathrm{CHO}), 9.85$ (s, 1H, OH), 7.42-6.77 (m, 7H), $4.95\left(\mathrm{~s}, 2 \mathrm{H}, \mathrm{OCH}_{2}\right), 2.86-1.67$ $(\mathrm{m}, 16 \mathrm{H}) ;{ }^{13} \mathrm{C} \mathrm{NMR}\left(\mathrm{CDCl}_{3}, 63 \mathrm{MHz}\right) \delta 196.7,156.6,156.1$, $152.9,147.0,140.0,136.9,133.9,133.4,130.8,130.1,129.6$, $129.3,125.9,125.3,124.6,124.5,123.5,118.6,111.1,69.5$, 29.3, 29.0,28.1 , 27.0, 23.0, 22.9, 22.7, 22.6, 21.0; HRMS (FAB) calcd for $\mathrm{C}_{29} \mathrm{H}_{34} \mathrm{~N}_{3} \mathrm{O}_{3}: 472.2595$; found: $472.2588 ;[\alpha]_{\mathrm{D}}=1.09$ (c $18.3, \mathrm{CHCl}_{3}$ ).

Acknowledgments. This work was supported by the grants from the Ministry of Science \& Technology of Korea through NRL program (K.M. Kim) and from the Basic Research Program through the NRF (20090063004 for K.M. Kim and S.-g. Lee), KRF (2024-005-C00093), and R01-2006-10696 from the Korea Science and Engineering Foundation.

\section{References}

1. (a) Coppola, G. M.; Schuster, H. F. Asymmetric Synthesis: Construction of Chiral Molecules Using Amino Acids; Wiley: New York, NY, 1987. (b) Bergmeier, S. C. Tetrahedron 2000, 56, 2561.

2. (a) Noyori, R. Asymmetric Catalysis in Organic Synthesis; John Wiley and Sons: New York, NY, 1994. (b) Helmchen, G.; Pfaltz, A. Acc. Chem. Res. 2000, 33, 336. (c) Ager, D. J.; Prakash, I.; Schaad, D. R. Chem. Rev. 1996, 96, 835.

3. (a) Wang, Q.; Chen, X.; Tao, L.; Wang, L.; Xiao, D.; Yu, X.-Q; Pu, L. J. Org. Chem. 2007, 72, 97. (b) Dai, Z.; Xu, X.; Canary, J. W. Chirality 2005, 17, S227. (c) Lee, S. J.; Lin, W. J. Am. Chem. Soc. 2002, 124, 4554. (d) Liu, Y.; Li, B.; Wada, T.; Inoue, Y. Tetrahedron 2001, 57, 7153.

4. (a) Folmer-Andersen, J. F.; Lynch, V. M.; Anslyn, E. V. J. Am.
Chem. Soc. 2005, 127, 7986. (b) Breccia, P.; Van Gool, M.; PérezFernández, R.; Martin-Santamaria, S.; Gago, F.; Prados, P.; Mendoza, J. J. Am. Chem. Soc. 2003, 125, 8270. (c) Oliva, A. I.; Simón, L.; Hernández, J. V.; Muñiz, F. M.; Lithgow, A.; Jiménez, A.; Morán, J. R. J. Chem. Soc., Perkin Trans. 2 2002, 1050. (d) Osawa, T.; Shirasaka, K.; Matsui, T.; Yoshihara, S.; Akiyama, T.; Hishiya, T.; Asanuma, H.; Komiyama, M. Macromolecules 2006, 39, 2460. (e) Tsubaki, K.; Tanima, D.; Nuruzzaman, M.; Kusumoto, T.; Fuji, K.; Kawabata, T. J. Org. Chem. 2005, 70, 4609. (f) Famulok, M. Science 1996, 272, 1343. (g) Chin, J.; Lee, S. S.; Lee, K. J.; Park, S.; Kim, D. H. Nature 1999, 401, 254.

5. (a) Bradshaw, J. S.; Izatt, R. M.; Bordunov, A. V.; Zhu, C. Y.; Hathaway, J. K. Comprehensive Supramolecular Chemistry; Gokel, G. W., Ed.; Pergamon: New York, NY, 1996; Vol. 1, pp 35-95. (b) Zhang, X. X.; Bradshaw, J. S.; Izatt, R. M. Chem. Rev. 1997, 97 , 3313. (c) Kim, J.; Raman, B.; Ahn. K. H. J. Org. Chem. 2006, 71, 38. (d) Kim, S.-G.; Kim, K.-H.; Kim, Y. K.; Shin, S. K.; Ahn, K. H. J. Am. Chem. Soc. 2003, 125, 13819. (e) Hirose, K.; Fujiwara, A.; Matsunaga, K.; Aoki, N.; Tobe, Y. Tetrahedron Lett. 2002, 43, 8539. (f) Kurtán, T.; Nesnas, N.; Li, Y.-Q.; Huang, X.; Nakanishi, K.; Berova, N. J. Am. Chem. Soc. 2001, 123, 5962.

6. (a) Cram, D. J. Angew. Chem., Int. Ed. Engl. 1988, 27, 1009. (b) Lehn, J.-M. Angew. Chem., Int. Ed. Engl. 1988, 27, 89.

7. (a) Meyer, C. D.; Joiner, C. S.; Stoddart, J. F. Chem. Soc. Rev. 2007, 36, 1705. (b) Feuster, E. K.; Glass, T. E. J. Am. Chem. Soc. 2003, $125,16174$.

8. (a) Kim, K. M.; Park, H.; Kim, H.-J.; Chin, J.; Nam, W. Org. Lett. 2005, 7, 3525. (b) Tang, L.; Choi, S.; Nandhakumar, R.; Park, H.; Chung, H.; Chin J.; Kim, K. M. J. Org. Chem. 2008, 73, 5996.

9. (a) Chin, J.; Mancin, F.; Thavarajah, N.; Lee, D.; Lough, A.; Chung, D. S. J. Am. Chem. Soc. 2003, 125, 15276. (b) Gilli, G.; Bellucci, F.; Ferretti, V.; Bertolasi, V. J. Am. Chem. Soc. 1989, 111, 1023.

10. (a) Park, H.; Kim, K. M.; Lee, A.; Ham, S.; Nam, W.; Chin, J. J. Am. Chem. Soc. 2007, 129, 1518. (b) Nandhakumar, R.; Ryu, J.; Park, H.; Tang, L.; Choi, S.; Kim, K. M. Tetrahedron 2008, 64, 7704. (c) Tang, L.; Ga, H.; Kim, J.; Choi, S.; Nandhakumar, R.; Kim, K. M. Tetrahedron Lett. 2008, 49, 6914.

11. (a) Park, H.; Hong, J.; Ham, S.; Nandhakumar, R.; Kim, K. M. Bull. Kor. Chem. Soc. 2009, 30, 409. (b) Park, H.; Nandhakumar, R.; Hong, J.; Ham, S.; Chin, J.; Kim, K. M. Chem. Eur. J. 2008, 14,9935

12. (a) Shaw, J. P.; Petsko, G. A.; Ringe, D. Biochemistry 1997, 36, 1329. (b) Walsh, C. T. J. Biol. Chem. 1989, 264, 23936.

13. (a) Gilli, P.; Bertolasi, V.; Ferretti, V.; Gilli, G. J. Am. Chem. Soc. 2000, 122, 10405. (b) Kim, H.-J.; Kim, W.; Lough, A. J.; Kim, B. M.; Chin, J. J. Am. Chem. Soc. 2005, 127, 16776.

14. Nandhakumar, R.; Ahn, Y. S.; Hong, S.; Ham, S.; Kim, K. M. Tetrahedron 2009, 65, 666 .

15. (a) Takasaki, M.; Motoyama, Y.; Yoon, S-Ho.; Mochida, I.; Nagashima, H. J. Org. Chem. 2007, 72, 10291. (b) Au-Yeung, T. T.-L.; Chan, S.-S.; Chan, A. S. C. Adv. Synth. Catal. 2003, 345, 357 and references cited therein.

16. Hofsløkken, N. U.; Skattebøl, L. Acta Chem. Scand. 1999, 53, 258.

17. $K_{R}=[2-R-a a l] /([2][R-a a l])$ and $K_{S}=[2-S-a a l] /([2][S-a a l])$, where aal $=$ amino alcohol. $K_{R} / K_{S}=([2-R-a a l][S-a a l]) /([2-S-a a l][R-a a l])=$ $([2-R-a a l] /[2-S-a a l])^{2}$ when $[\mathbf{2}]_{0}=[R-a a l]_{0}=[S-a a l]_{0}$.

18. Mazik, M.; Cavga, H. J. Org. Chem. 2007, 72, 831. 